\title{
Selenium-enriched milk proteins and selenium yeast affect selenoprotein activity and expression differently in mouse colon
}

\author{
Ying $\mathrm{Hu}^{*}$, Graeme H. McIntosh, Richard K. Le Leu and Graeme P. Young \\ Flinders Centre for Cancer Prevention and Control, Flinders University of South Australia, Bedford Park 5042, Australia
}

(Received 12 October 2009 - Revised 10 December 2009 - Accepted 14 December 2009 - First published online 29 March 2010$)$

Certain forms of dietary Se may have an advantage in improving Se status and reducing cancer risk. The present study compared the effects of an Se-enriched milk protein product (dairy-Se) with an Se yeast (yeast-Se) on selenoprotein activity and expression in the mouse colon. Mice were fed four diets for 4 weeks: a control milk protein diet (Se at 0.068 parts per million (ppm)), dairy-Se diets with Se at 0.5 and $1 \mathrm{ppm}$, and a yeast-Se diet with Se at $1 \mathrm{ppm}$. Cytosolic glutathione peroxidase-1 (GPx-1) activity, mRNA of selenoprotein $\mathrm{P}(\mathrm{SeP}), G P x$ - 1 , gastrointestinal glutathione peroxidase-2 $(G P x-2)$ and thioredoxin reductase-1 $(\operatorname{Tr} x R-1)$ were examined in the mouse colon. Dairy-Se diets did not significantly affect $G P x-1$ mRNA and GPx-1 activity but produced a dose-dependent increase in $S e P$ and $G P x-2 \mathrm{mRNA}$, with a significantly higher level achieved at $1 \mathrm{ppm}$ Se $(P<0 \cdot 05)$. Yeast-Se at $1 \mathrm{ppm}$ significantly increased $G P x-1$ mRNA and GPx-1 activity $(P<0 \cdot 01)$ but not $G P x-2$ mRNA. Neither Se supplement had any effect on $\operatorname{Tr} x R-1$. The present study indicates that selenoprotein levels in the mouse colon are regulated differently depending on the Se supplement. As we have previously shown that dairy-Se at $1 \mathrm{ppm}$ was protective against colorectal cancer (CRC) in an azoxymethaneinduced CRC mouse model, this up-regulation of colonic $G P x-2$ and $S e P$ with Se supplementation may be crucial to its chemopreventive action.

\section{Selenium: Selenoproteins: Colon cancer prevention}

Se, as an essential micronutrient, is required for a number of metabolically important enzymes, and its importance for human health and prevention of disease is well established ${ }^{(1)}$. Se deficiency predisposes to a variety of major human diseases including cancer ${ }^{(2)}$; conversely, intakes of $\mathrm{Se}$ above the normal recommended nutritional intake (supra-nutritional) are associated with reduced risk for a range of cancers ${ }^{(3)}$. In fact, Se intakes in many parts of the world are below the present dietary reference values because commonly consumed foods are often poor Se sources ${ }^{(4)}$. Consequently, Se-enriched foods are likely to be beneficial for increasing human Se intake, and perhaps, reducing cancer risk. For instance, Se-enriched plant foods have been shown to significantly protect against colorectal cancer (CRC) in animal models ${ }^{(5,6)}$.

An Se-enriched milk protein product (dairy-Se) has recently been developed as a novel food product by Tatura Milk Industries of Australia. Milk is not normally a major dietary source of $\mathrm{Se}$, but $\mathrm{Se}$ concentration in milk proteins can be readily increased to 5 parts per million (ppm) by feeding appropriate Se sources to cows ${ }^{(7,8)}$. We have shown that such a dairy source of Se produced higher plasma Se levels and significantly suppressed colon cancer incidence and relevant biomarkers of CRC risk, for example, aberrant crypt foci relative to equivalent $\mathrm{Se}$ amounts as $\mathrm{Se}$ yeast (yeast-Se) ${ }^{(9)}$. This suggests that delivery of Se through dairy products potentially provides a good opportunity for safely improving human Se status and in the longer term reducing the risk of CRC.
Se is essential for a wide range of biological functions, which are mediated by at least twenty-five selenoproteins ${ }^{(10)}$; some selenoproteins are particularly relevant to anticancer function in the gastrointestinal tract ${ }^{(11,12)}$, such as cytosolic glutathione peroxidase (GPx-1), gastrointestinal glutathione peroxidase (GPx-2), selenoprotein $\mathrm{P}(\mathrm{SeP})$ and thioredoxin reductase-1 (TrxR-1). For instance, a link between selenoproteins and colon cancer risk has been reported by genetic data and animal models ${ }^{(13-16)}$ and functional polymorphisms in selenoprotein genes have also been linked to human cancer risk $^{(17)}$. It has been proposed that genetic variation in selenoprotein genes could affect their function(s), their response to dietary Se intake and cancer risk ${ }^{(14)}$. As far as Se and selenoproteins are concerned, studies so far have mostly relied on the assessment of blood or plasma SeP concentration and GPX-1 activity, or focused on Se deficiency and alteration in selenoprotein level $^{(18)}$, or compared selenoprotein expression pattern between cancers and normal tissues ${ }^{(11,19-21)}$. How dietary supplementation of Se may influence selenoprotein activity and expression in the colon has been examined only in a few animal studies ${ }^{(22)}$; those studies did not include giving animals diets with higher Se levels than the normal recommended nutritional range. Activity or expression of specific selenoproteins in target tissues is likely to provide considerable insights into the possible involvement of those selenoproteins in health benefits including cancer prevention ${ }^{(19)}$. The purpose of the present study was to compare a dairy-Se with a yeast-Se for

Abbreviations: CRC, colorectal cancer; dairy-Se, Se-enriched milk proteins; GPx-1, cytosolic glutathione peroxidase-1; GPx-2, gastrointestinal glutathione peroxidase-2; ppm, parts per million; SeP, selenoprotein P; TrxR-1, thioredoxin reductase-1; yeast-Se, Se yeast.

* Corresponding author: Dr Ying Hu, fax +61 88204 3943, email ying.hu@ flinders.edu.au 
their effects on $S e P, G P x-1, G P x-2$ and $\operatorname{Tr} x R-1$ expression and GPX-1 activity in the mouse colon.

\section{Materials and methods}

\section{Selenium supplements}

Dairy-Se (TaturaBio ${ }^{\circledR} \mathrm{Se}$ ) was produced by Tatura Milk Industries (Tatura, VIC, Australia). It is a milk protein isolate with a high Se concentration (about 5 ppm), compared with control milk proteins $(0.34 \mathrm{ppm})$; Yeast-Se (Sel-Plex ${ }^{\circledR} ; 1800 \mu \mathrm{g} \mathrm{Se} / \mathrm{g}$ dry weight) was provided by Alltech Biotechnology $\mathrm{P} / \mathrm{L}$ (Dandenong South, VIC, Australia).

\section{Animals}

A total of forty-eight wild-type male mice of the C57BL/6J strain were obtained from the Animal Resource Centre, Perth, Australia. Animal protocols were approved by the Animal Welfare Committee at Flinders University of South Australia (reference 593/04). Mice were divided randomly into four equal experimental groups, housed in cages (four per cage) and maintained in a temperature- and humiditycontrolled animal facility with a $12 \mathrm{~h}$ light-dark cycle at $22 \pm 2{ }^{\circ} \mathrm{C}$ temperature and $80 \pm 10 \%$ humidity. Mice were given free access to water.

\section{Diets}

The experimental diets fed to the mice were based on a modified form of the American Institute of Nutrition (AIN)-76A diet for rodents ${ }^{(23)}$ and have been described by us previously $^{(9)}$. Control milk proteins and dairy-Se were used as protein sources; however, because the dairy protein sources have relatively high $\mathrm{Ca}$ concentrations, $\mathrm{Ca}$ was not included in the diets. The four diet groups were: (1) milk protein control diet (Se at 0.068 ppm); (2) dairy-Se diet (Se at 0.5 ppm); (3) dairy-Se diet (Se at $1 \mathrm{ppm})$; (4) milk protein control + yeast-Se diet (Se at $1 \mathrm{ppm})$. Details of the diets are provided in Table 1.

\section{Experimental procedures}

Mice, aged 10 weeks, were assigned to each of the four diets (twelve mice per group). After 4 weeks on the diet, mice were killed by cardiac puncture after ketamine-xylazine anaesthesia. Part of the colon was placed in RNAlater ${ }^{\circledR}$ (Ambion, Austin, TX, USA) solution at $4^{\circ} \mathrm{C}$ for $24 \mathrm{~h}$, and stored at $-80^{\circ} \mathrm{C}$ until real-time PCR analysis; the remaining colon was fresh frozen immediately in liquid $\mathrm{N}_{2}$ and stored at $-80^{\circ} \mathrm{C}$ for assay of GPx-1 activity.

\section{Assay of glutathione peroxide-1 activity}

GPX-1 activity in the mouse colon was measured by a commercially available Glutathione Peroxidase Cellular Activity Assay Kit (Sigma, Sydney, NSW, Australia), using cumene hydroperoxide as a substrate. The colon was cut open, the mucosa scraped off and homogenised in a buffer containing $1 \mathrm{M}$-2-amino-2-hydroxymethyl-propane-1,3-diol (Tris) ( $\mathrm{pH} 7 \cdot 6$ ) and $0.5 \mathrm{M}$-EDTA and centrifuged at $9391 \mathrm{~g}$ for $20 \mathrm{~min}$ at $4^{\circ} \mathrm{C}$. The protein concentration was quantified using a Protein Assay Kit (Bio-Rad, Hercules, CA, USA). GPX-1 activity was determined in duplicate using $2 \cdot 5-5 \mu$ l of the supernatant fraction (15-30 $\mu \mathrm{g}$ of proteins), assayed in a $100 \mu \mathrm{l}$ reaction volume containing $5 \mathrm{~mm}-\mathrm{NADPH}, 30 \mathrm{~mm}-\mathrm{H}_{2} \mathrm{O}_{2}$ and $42 \mathrm{~mm}-$ reduced glutathione. The oxidation of NADPH to NADP was monitored at $340 \mathrm{~nm}$ on a UV-Vis spectrophotometer. A quantity of 1 unit of glutathione peroxidase will cause the formation of $1 \mu \mathrm{mol}$ of NADP from NADPH per min in the presence of reduced glutathione, glutathione reductase, and tert-butyl hydroperoxide. GPx-1 activity was expressed as $\mathrm{U} / \mathrm{mg}$ protein.

\section{RNA isolation and cDNA synthesis}

Total RNA was extracted from the mouse colon $(30 \mathrm{mg})$ using a QIAGEN RNeasy Mini Kit (QIAGEN, Hilden, Germany). The concentration and purity of the total RNA was estimated using a NanoDrop ${ }^{\circledR}$ ND-1000 UV-Vis spectrophotometer by measuring the absorbance at 260 and $280 \mathrm{~nm}$. All RNA samples had a 260:280 absorbance ratio between 1.9 and $2 \cdot 1$. First-strand cDNA $(20 \mu \mathrm{l})$ was synthesised from $0 \cdot 3 \mu \mathrm{g}$

Table 1. Composition of experimental diets ( $\mathrm{g} / 100 \mathrm{~g}$ diet)

\begin{tabular}{|c|c|c|c|c|}
\hline Ingredient & Control diet (Se at $0.1 \mathrm{ppm})$ & Dairy-Se diet (Se at $0.5 \mathrm{ppm})$ & Dairy-Se diet (Se at $1 \mathrm{ppm})$ & Yeast-Se diet (Se at $1 \mathrm{ppm})$ \\
\hline Casein* & 0 & 0 & 0 & 0 \\
\hline Milk protein* & 20 & 10 & 0 & 20 \\
\hline Tatura-Bio ${ }^{\circledR} \mathrm{Se}^{*} \dagger$ & 0 & 10 & 20 & 0 \\
\hline Sucrose & 20 & 20 & 20 & 20 \\
\hline Maize starch & $31 \cdot 3$ & $31 \cdot 3$ & $31 \cdot 3$ & $31 \cdot 2$ \\
\hline Fibre $(\alpha$ cell $)$ & 5 & 5 & 5 & 5 \\
\hline Sunflower-seed oil & 19 & 19 & 19 & 19 \\
\hline Choline & 0.2 & 0.2 & 0.2 & 0.2 \\
\hline Mineral mix & 3.5 & 3.5 & 3.5 & 3.5 \\
\hline Vitamin mix & 1 & 1 & 1 & 1 \\
\hline Sel-Plex ${ }^{\circledR} \dagger$ & 0 & 0 & 0 & 0.1 \\
\hline
\end{tabular}

ppm, Parts per million; dairy-Se, Se-enriched milk proteins; yeast-Se, Se yeast

${ }^{\star}$ Milk protein was used as the protein source for the control diet and the yeast-Se diet; Tatura-Bio ${ }^{\circledR}$ Se (Tatura Milk Industries, Tatura, VIC, Australia) was used as the protein source for the dairy-Se diets (Se at 0.5 and $1 \mathrm{ppm}$ ).

†Tatura-Bio ${ }^{\circledR}$ Se was used as the Se source for the dairy-Se diets (Se at 0.5 and 1 ppm); Sel-Plex ${ }^{\circledR}$ (Alltech Biotechnology P/L, Dandenong South, VIC, Australia) was used as the Se source for the yeast-Se diet. 
Table 2. Oligonucleotide primers used for real-time PCR

\begin{tabular}{|c|c|c|c|}
\hline Gene & $\begin{array}{c}\text { Gene } \\
\text { accession no. }\end{array}$ & Primers & Primer sequence $5^{\prime}-3^{\prime}$ \\
\hline $\mathrm{SeP}$ & NM_009155 & Sense & TTGGTTTGCCTTACTCCTTCCT \\
\hline & & Antisense & TTGTGGTGGCTATGAGCCTCT \\
\hline$G P x-1$ & NM_008160 & Sense & ATCAGTTCGGACACCAGGAG \\
\hline & & Antisense & TCACCATTCACTTCGCACTTC \\
\hline$G P x-2$ & NM_030677 & $\begin{array}{l}\text { Sense } \\
\text { Antisense }\end{array}$ & $\begin{array}{l}\text { TAGTTCTCGGCTTCCCTTGC } \\
\text { AAGACAGGATGCTCGTTCTGC }\end{array}$ \\
\hline $\operatorname{Trx} R$ & NM_015762 & $\begin{array}{l}\text { Sense } \\
\text { Antisense }\end{array}$ & $\begin{array}{l}\text { TATGTCGCCTTGGAATGTGCAG } \\
\text { ATGGTCTCCTCGCTGTTTGTG }\end{array}$ \\
\hline GAPDH & NM_008935 & $\begin{array}{l}\text { Sense } \\
\text { Antisense }\end{array}$ & $\begin{array}{l}\text { AACATCATCCCTGCATCCAC } \\
\text { TTGAAGTCRCAGGAGACAAC }\end{array}$ \\
\hline
\end{tabular}

$\mathrm{SeP}$, selenoprotein $\mathrm{P} ; \mathrm{GPx}-1$, cytosolic glutathione peroxidase-1; $G P x-2$, gastrointestinal glutathione peroxidase-2; $\operatorname{Tr} R$, thioredoxin reductase; $G A P D H$, glyceraldehyde 3-phosphate dehydrogenase.

total RNA for each sample using a QIAGEN QuantiTect Reverse Transcription Kit (QIAGEN). cDNA was diluted 1:30 with nuclease-free water and used for real-time PCR.

\section{Real-time PCR}

Real-time quantitative PCR of the four genes was performed in triplicate on a Rotor-Gene 3000 Cycler (Corbett, Sydney, NSW, Australia). Oligonucleotide primers were designed using Primer Express software v. 1.5 (Applied Biosystems, Inc., Foster City, CA, USA), based on sequences from the Genbank database (Table 2). All PCR reagents were purchased from QIAGEN. The PCR reaction was determined in a $20 \mu \mathrm{l}$ final volume containing $6 \mu \mathrm{l}$ of diluted cDNA and $2 \times$ QuantiTect SYBR Green PCR Kit. The primer concentration for each gene was $10 \mu \mathrm{M}$ (forward and reverse primer). The cycling protocol started with an initial hot-start at $95^{\circ} \mathrm{C}$ for $15 \mathrm{~min}$, followed by forty-five cycles at $94^{\circ} \mathrm{C}$ for $15 \mathrm{~s}, 60^{\circ} \mathrm{C}$ for $30 \mathrm{~s}$ and $72^{\circ} \mathrm{C}$ for $30 \mathrm{~s}$, and finished with a final extension at $72^{\circ} \mathrm{C}$ for $4 \mathrm{~min}$. The specificity of PCR was confirmed by melting-curve analysis with only one peak being present for PCR products of $S e P, G P x-1, G P x-2$ and TrxR-1 genes, and of the housekeeping gene of glyceraldehyde 3-phosphate dehydrogenase $(G A P D H)$. For each PCR run, a non-template reaction was included as negative controls.

Cycle thresholds were determined using the relative quantification analysis module in the Rotor-Gene 3000 Series software (Corbett). The amplification efficiency of each primer pair was estimated from a real-time PCR dilution curve generated using serial dilutions of cDNA. Real-time quantitative PCR analysis was then performed using Q-Gene software ${ }^{(24)}$; with the amplification efficiency applied to the relative concentration analyses of both the genes of interest and the housekeeping gene $(G A P D H)$. Gene of interest expression data were normalised by dividing the corresponding levels of $G A P D H$ for each sample.

\section{Statistical analyses}

Statistical analyses were performed using SPSS for Windows, version 14.0 (SPSS Inc., Chicago, IL, USA). Data were expressed as mean values with their standard errors. Between-group comparisons for each gene were assessed using one-way ANOVA with correction for multiple comparisons by Tukey's post hoc test. Differences between groups were considered significant when $P<0 \cdot 05$.

\section{Results}

Effects of dietary selenium intake on cytosolic glutathione peroxidase-1 activity in mouse colon

The effects of dietary Se intake on mouse colon GPx-1 activity are shown in Table 3 . After 4 weeks on the diets with different Se forms and concentrations, GPx-1 activity differed in mouse colon across the four diets. GPx-1 activity in mice fed the yeast-Se diet with Se at $1 \mathrm{ppm}$ was significantly higher $(8.12$ (SEM 0.63$) \mathrm{U} / \mathrm{mg}$ protein) than in those on the control diet $(5.85$ (SEM 0.63$) \mathrm{U} / \mathrm{mg}$ protein) $(P<0 \cdot 01)$. However, GPx-1 activity in mice fed dairy-Se diets did not differ significantly across the doses tested; it was 6.15 (SEM 0.57) $\mathrm{U} / \mathrm{mg}$ protein in mice fed at $0.5 \mathrm{ppm}$ and 5.95 (SEM 0.75 ) $\mathrm{U} / \mathrm{mg}$ protein in mice fed at $1 \mathrm{ppm}$.

\section{Expression of selenoprotein $P$, cytosolic glutathione peroxidase-1, gastrointestinal glutathione peroxidase-2 and thioredoxin reductase-1 mRNA in mouse colon}

Selenoprotein gene expression was analysed by quantitative real-time PCR. The expression pattern of $S e P, G P x-1, G P x-2$ and $\operatorname{Tr} x R-1$ in the mouse colon was comparable with those reported in previous studies in human subjects and rodents $^{(25,26)}$. Our data showed that $\mathrm{SeP}$ was the major selenoprotein expressed in mouse colon with a relative expression level of 2.56 (SEM 0.33), followed by $G P x-1$ and $G P x-2$, with a relative expression level of 0.93 (SEM 0.21 ) and 0.88 (SEM 0.22), respectively. $\operatorname{Tr} x R-1$ was also observed in

Table 3. Effects of dietary supplementation of selenium on cytosolic glutathione peroxidase-1 (GPx-1) activity in mouse colon

(Mean values with their standard errors)

\begin{tabular}{|c|c|c|c|c|c|c|c|c|}
\hline & \multicolumn{2}{|c|}{$\begin{array}{c}\text { Control diet } \\
\text { (Se at } 0.1 \mathrm{ppm}) \\
(n 12)\end{array}$} & \multicolumn{2}{|c|}{$\begin{array}{c}\text { Dairy-Se diet } \\
\text { (Se at } 0.5 \mathrm{ppm}) \\
(n 12)\end{array}$} & \multicolumn{2}{|c|}{$\begin{array}{l}\text { Dairy-Se diet } \\
\text { (Se at } 1 \mathrm{ppm}) \\
\quad(n 12)\end{array}$} & \multicolumn{2}{|c|}{$\begin{array}{l}\text { Yeast-Se diet } \\
\text { (Se at } 1 \mathrm{ppm}) \\
(n 12)\end{array}$} \\
\hline & Mean & SEM & Mean & SEM & Mean & SEM & Mean & SEM \\
\hline $\begin{array}{l}\text { GPx-1 activity } \\
\text { (U/mg protein) }\end{array}$ & $5 \cdot 85$ & 0.63 & $6 \cdot 15$ & 0.57 & 5.95 & 0.75 & $8 \cdot 12^{\star}$ & 0.63 \\
\hline
\end{tabular}

ppm, Parts per million; dairy-Se, Se-enriched milk proteins; yeast-Se, Se yeast.

${ }^{\star}$ Mean value was significantly different from that of the control diet $(P<0.01$; ANOVA). 
mouse colon but expressed at a relative lower level of 0.062 (SEM 0.04) (Table 4).

Effects of dietary selenium on selenoprotein $P$, cytosolic glutathione peroxidase-1, gastrointestinal glutathione peroxidase- 2 and thioredoxin reductase- $1 \mathrm{mRNA}$ in mouse colon

Fold changes of colonic $S e P, G P x-1, G P x-2$ and $\operatorname{Tr} x R$ mRNA in response to dietary Se supplementation relative to control are shown in Fig. 1. After 4 weeks of Se supplementation, selenoprotein gene expression in the mouse colon responded differently depending on the Se supplement. SeP mRNA

(a)

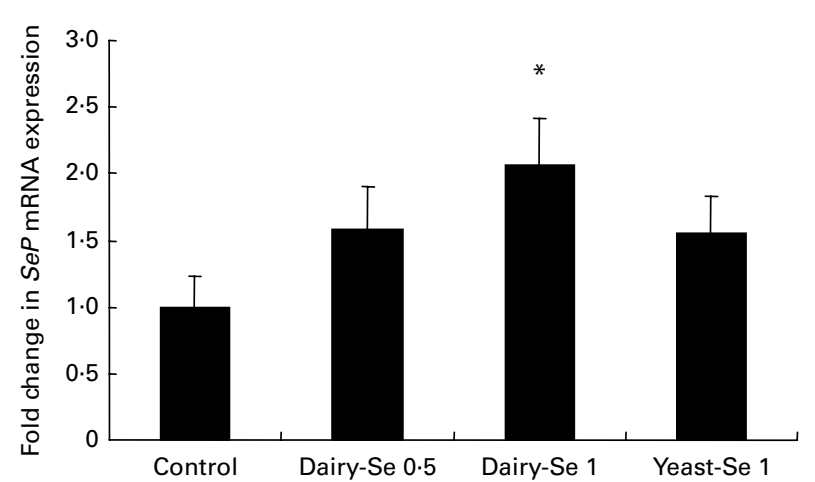

(c)

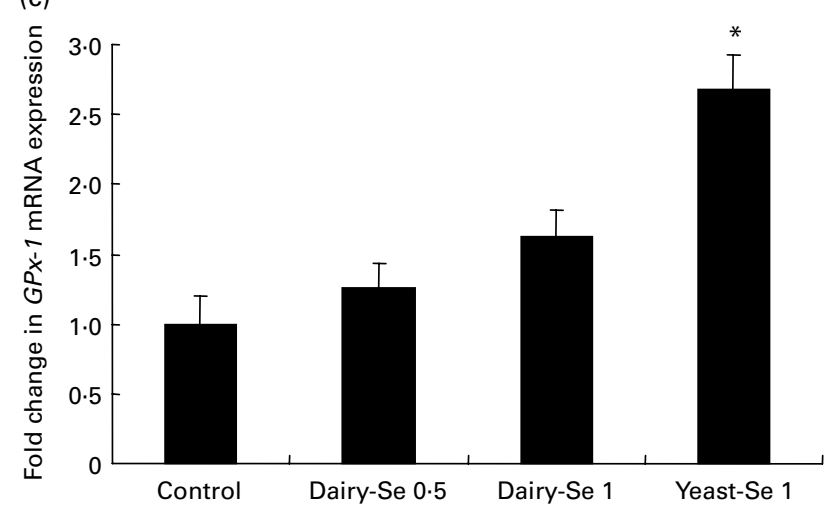

level increased in a dose-dependent manner in response to dairy-Se diets, being significantly higher $(>2$-fold) in mice fed dairy-Se with Se at $1 \mathrm{ppm}$ than those on the control diet $(P<0.05)$ (Fig. 1(a)). A trend to increased $S e P$ mRNA was also found in mice fed equivalent $1 \mathrm{ppm}$ Se as yeast-Se, but it was not significantly different compared with that of the control diet $(P=0 \cdot 068)$. Increases in $G P x-2 \mathrm{mRNA}$ levels in response to dairy-Se diets were also dose-dependent, with a significantly higher level of GPx-2 mRNA (1.9-fold) found in mice fed dairy-Se with $\mathrm{Se}$ at $1 \mathrm{ppm}$, compared with mice fed the control diet $(P<0.05)$ (Fig. 1(b)); however, yeast-Se did not significantly affect $G P x-2$ mRNA expression in the mouse colon. In the case of $G P x-1$, a significantly higher (b)

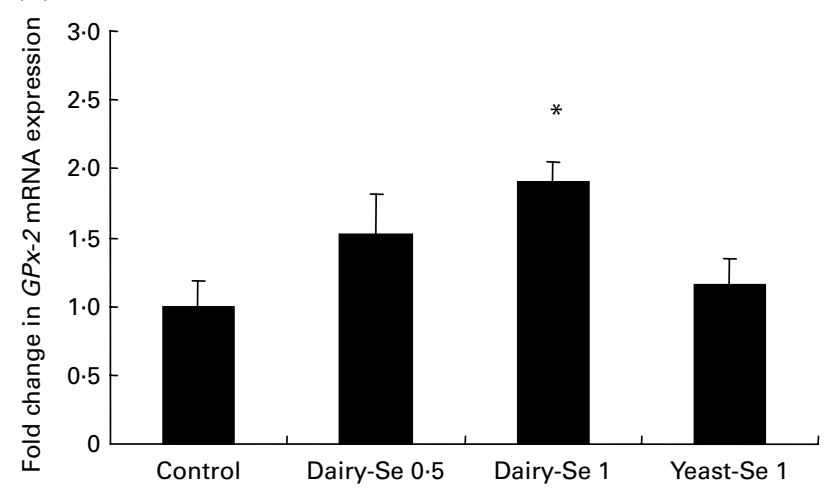

(d)

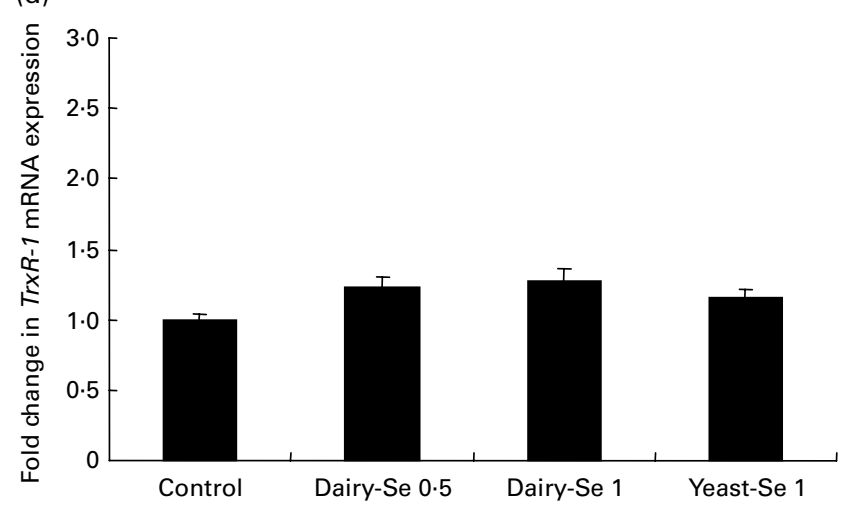

Fig. 1. Effects of dietary supplementation of Se on selenoprotein $\mathrm{P}(\mathrm{Se} P$ ) (a), gastrointestinal glutathione peroxidase-2 (GPX-2) (b), cytosolic glutathione peroxidase-1 $(G P x-1)(c)$ and thioredoxin reductase-1 (TrxR-1) (d) mRNA expression in the mouse colon. Data are fold changes of colonic SeP, GPx-2, GPx-1 and TrxR-1 mRNA expression in response to dietary Se supplementation, relative to control, with control expression set at 1 . Gene expression values have been normalised against the reference gene of glyceraldehyde 3-phosphate dehydrogenase (GAPDH). Dairy-Se 0.5, Se-enriched milk proteins (Se at 0.5 parts per million $(\mathrm{ppm})$ ); Dairy-Se 1, Se-enriched milk proteins (Se at $1 \mathrm{ppm})$; Yeast-Se 1, Se yeast (Se at $1 \mathrm{ppm})$. Values are means ( $n$ 12), with standard errors represented by vertical bars. * Mean value was significantly different from that for the control diet $(P<0.05$; ANOVA). 
GPX-1 mRNA level was found in mice fed the yeast-Se diet with Se at $1 \mathrm{ppm}$; it was $2 \cdot 7$-fold higher than those on the control diet $(P<0.05)$ (Fig. 1(c)). A trend of higher GPx-1 mRNA was also found in mice fed the dairy-Se diet at $1 \mathrm{ppm}$, but it was not significant compared with those on the control diet $(P=0 \cdot 060)$. Our data indicated that the increased expression of $G P x-1$ mRNA in the mouse colon was reflected in that of GPX-1 activity after dietary Se supplementation. However, TrxR-1 mRNA level was not changed by dietary Se supplementation either from the dairy or yeast source (Fig. 1(d)).

\section{Discussion}

There is evidence from in vitro and in vivo studies that dietary supplementation of Se across a significant concentration range may regulate selenoproteins in target tissues ${ }^{(27-30)}$. In the case of the colon, the expression of several selenoprotein genes is significantly affected in animals fed Se-deficient diets compared with those fed Se-adequate diets ${ }^{(18,22)}$. However, little is known about whether selenoproteins in the colon are regulated by increasing Se intake beyond what is considered nutritionally adequate ( 1.5 to 10 times recommended adequate dietary intake), and whether the regulation is dependent on Se form. In the present study, we showed for the first time that colonic selenoprotein levels, namely SeP, GPx-1 and GPX-2 in the mouse colon were regulated differently depending on the Se form. We found that dairy-Se at $1 \mathrm{ppm}$ significantly increased expression of colonic $\mathrm{SeP}$ and $G P x-2$ mRNA but did not affect $G P x-1$, in particular GPx-1 activity, whereas yeast-Se at $1 \mathrm{ppm}$ significantly increased colonic $G P x-1$ mRNA and GPx-1 activity without affecting $S e P$ and $G P x-2$ mRNA. Studies from human clinical trials and animal experiments indicated that the chemical form of Se and not Se per se was the critical determinant of Se bioavailability and Se efficacy ${ }^{(31-34)}$. Our data support this concept, for while Se in both dairy and yeast sources is present as selenomethionine at $83 \%$ and as selenocysteine at about $5 \%$, dairy-Se does not contain low-molecular-weight Se compounds due to the preparative procedure (filtration at $10 \mathrm{kDa}$ ), whereas yeast-Se contains $3 \%$ of selenite. Additionally, dairy-Se also contains $4 \%$ unknown components ${ }^{(35)}$; thus future studies are needed to identify organic species existing in dairy-Se. It is possible that the different Se forms may account for their different effects by affecting Se metabolism, Se delivery to target tissues, and subsequent selenoprotein synthesis, expression and function.

The beneficial effects of Se are thought to be mediated through the function of selenoproteins. Our particular interest is the potential regulation of $S e P, G P x-1, G P x-2$ and $\operatorname{Tr} x R-1$ in the colon by Se supplementing due to their potential relevance to CRC prevention. Our data support the view that SeP and GPX-2 along with GPx-1 are three selenoproteins of major functional significance in the mouse $\operatorname{colon}^{(12,26)}$. As they responded significantly to supra-nutritional levels of $\mathrm{Se}$ intake, they may represent intestinal targets for Se supplementation aimed not at correcting deficiency but at achieving levels thought sufficient to contribute to cancer prevention. A recent human study showed that Se supplementation predominantly affected the genes that function in protein biosynthesis, which were linked to increased selenoprotein expression in the target tissues ${ }^{(11)}$. Others have proposed that selenoprotein levels in targeted tissues may better reflect the functional selenoprotein activity than the plasma selenoprotein levels ${ }^{(36)}$, and be more relevant to the beneficial anticancer effects of Se.

$\mathrm{SeP}$ is a major plasma selenoprotein with a crucial role in $\mathrm{Se}$ transport ${ }^{(19)}$. The presence of SeP is thought to be vital in terms of influencing individual selenoprotein expression in different tissues ${ }^{(25,26,37)}$. Given its transport function, this might explain the effective influence of SeP on other individual selenoproteins in the colon. In addition, SeP can also function as antioxidative defence and cancer prevention. For instance, $\mathrm{SeP}$ knock-out mice were linked to increased cancer development ${ }^{(38)}$, a significant reduction or loss of $\mathrm{SeP}$ mRNA expression was observed in $\mathrm{CRC}^{(39)}$ and some genetic variants in $\mathrm{SeP}$ were associated with human advanced colorectal adenoma $^{(40)}$. But the potential role of SeP to CRC prevention remains speculative and further studies are needed.

GPx-1 and GPx-2 are the major proteins responsible for $70 \%$ GPx enzyme activity in the gastrointestinal tract. Unlike GPx-1 that is expressed in almost all tissues in the human body ${ }^{(41)}$, GPx-2 is expressed exclusively in the gastrointestinal tract, providing $50 \%$ of GPx activity ${ }^{(37)}$. GPX-1 and GPx-2 have diverse biological roles that involve antioxidant function, inhibition of hydroperoxide, balance oxidative stress and associated inflammation. Their roles in CRC prevention have also received much attention because GPx-1/ $G P x$-2 double knock-out mice progressively developed colitis and subsequent intestinal cancer ${ }^{(15,16,42)}$. The present study showed that supra-nutritional intakes of dairy-Se significantly increased colonic $G P x-2$ mRNA, and slightly increased $G P x-1$ mRNA, but failed to increase colonic GPx-1 activity, whereas yeast-Se significantly increased colonic $G P x-1$ mRNA and GPX-1 activity without increasing $G P x-2$ mRNA. Since our previous animal studies showed that it was dairy-Se that protected against CRC rather than yeast-Se ${ }^{(9)}$, up-regulation of GPx-2 may be of importance in terms of CRC prevention, particularly with regard to its tissue specificity and stability in Se deficiency (i.e. selenoprotein hierarchy) ${ }^{(40,43)}$.

In contrast to $G P x-1$, the lack of $G P x-2$ was more detrimental because one intact allele was sufficient to prevent intestinal inflammation $^{(4)}$, thereby indicating that it has anti-cancer effects rather than acting as an anti-inflammatory. GPx-2 is involved in cell growth and differentiation, suppression of cyclo-oxygenase- 2 expression ${ }^{(45)}$ and activation by the $\beta$-catenin-T cell factor (TCF) complex ${ }^{(46)}$. Its expression is also regulated by $\mathrm{Nrf2}$, a transcription factor that induces enzymes that are cytoprotective and tumour preventive ${ }^{(47)}$. But GPX-2 may have dual roles in carcinogenesis because GPx-2 was highly expressed in human colorectal adenomas and carcinomas ${ }^{(39,48,49)}$; some hypothesised that a beneficial role of $\mathrm{GPx}-2$ in carcinogenesis may depend on the stage of tumorigenesis ${ }^{(45)}$. During the initiation stage, GPX-2 can protect cells from oxidative damage and reduce cyclooxygenase- 2 expression and PGE2 production. One notable characteristic of $\mathrm{Se}$ is that its protective effects are more pronounced in the early stage of carcinogenesis ${ }^{(5,50-52)}$.

Whether GPX-1 has protective effects for cancer prevention remains an interesting topic for future research ${ }^{(53)}$. There were reports that genetic variants of the $G P x-1$ were associated with increased $\mathrm{CRC}$ risk, and loss of heterozygosity at the GPx-1 locus was involved with malignant progression ${ }^{(42)}$. 
These data, along with the differential expression patterns reported for GPX-1 in tumour $v$. normal tissues ${ }^{(54)}$, support the relevance of GPx-1 in cancer prevention ${ }^{(55)}$. However, increasing evidence has suggested that GPx-1 might not act as the prime mechanism of chemoprevention ${ }^{(16,56)}$ because it reached its maximum with adequate Se intake, and did not change appreciably when Se intake increased to the levels that were 10-fold higher; such levels are necessary to see chemopreventive effects in the animal models ${ }^{(57)}$. Since Se intake at a supra-nutritional level also reduced the risk of colon cancer in transgenic mice that had reduced GPx-1 expression, the chemopreventive effect of Se may not be dependent on $G P x-1$ expression ${ }^{(16)}$.

TrxR-1, as part of the thioredoxin system, is important in antioxidant defence, but it has dual and contradictory effects on tumour development ${ }^{(54)}$. Like GPx-2, TrxR-1 levels were highly expressed in a variety of tumour tissues in humans ${ }^{(39)}$. There are reports that Se may affect TrxR-1 in two ways; increasing with excess of Se intake and declining with continued high levels of $\mathrm{Se}$ intake ${ }^{(57)}$. Since the expression of $\operatorname{Tr} x R-1$ in the mouse colon was very low compared with $S e P, G P x-1$ and $G P x-2$, and it did not respond to Se supplement from either the dairy or yeast source, this suggests that the function of TrxR-1 in the colon might not be as important as SeP, GPx-1 and GPx-2.

In conclusion, the present study indicates that activity and expression of selenoproteins in the mouse colon is regulated differently by different dietary sources of Se, namely dairySe compared with yeast-Se. We have previously shown that dairy-Se at $1 \mathrm{ppm}$, but not yeast-Se at the same level, was protective against CRC in an azoxymethane-induced CRC mouse model. The present study shows that dairy-Se but not yeast-Se up-regulates colonic $G P x-2$ and $S e P$ mRNA expression, suggesting that regulation of these genes is important in the prevention of CRC.

\section{Acknowledgements}

This project was funded by the Gardiner Foundation Major Research and Development Project (Melbourne, VIC, Australia; project no. MP4/009). The authors thank the support from the Department of Primary Industries Victoria, Tatura Milk Industries Ltd (Tatura, VIC, Australia), Alltech Biotech Pty Ltd (Dandenong South, Vic. Australia), the Geoffrey Gardiner Foundation (Melbourne, VIC, Australia) and the National Health and Medical Research Council of Australia.

Y. H., G. M. and G. Y. were involved in the design of the study. Y. H. and R. L. L. were responsible for execution of the experimental work and data collection. Y. H. was responsible for the data analysis and writing of the manuscript.

None of the authors has conflicts of interest.

\section{References}

1. Rayman MP (2000) The importance of selenium to human health. Lancet 356, 233-241.

2. Schrauzer GN, White DA \& Schneider CJ (1977) Cancer mortality correlation studies - III: statistical associations with dietary selenium intakes. Bioinorg Chem 7, 23-31.

3. Naithani R (2008) Organoselenium compounds in cancer chemoprevention. Mini Rev Med Chem 8, 657-668.
4. Kafai MR \& Ganji V (2003) Sex, age, geographical location, smoking, and alcohol consumption influence serum selenium concentrations in the USA: third National Health and Nutrition Examination Survey, 1988-1994. J Trace Elem Med Biol 17, 13-18.

5. Finley JW, Davis CD \& Feng Y (2000) Selenium from high selenium broccoli protects rats from colon cancer. $J$ Nutr 130, 2384-2389.

6. Davis CD, Zeng H \& Finley JW (2002) Selenium-enriched broccoli decreases intestinal tumorigenesis in multiple intestinal neoplasia mice. J Nutr 132, 307-309.

7. Heard JW, Stockdale CR, Walker GP, et al. (2007) Increasing selenium concentration in milk: effects of amount of selenium from yeast and cereal grain supplements. J Dairy Sci 90, 4117-4127.

8. Ortman K \& Pehrson B (1999) Effect of selenate as a feed supplement to dairy cows in comparison to selenite and selenium yeast. J Anim Sci 77, 3365-3370.

9. $\mathrm{Hu}$ Y, McIntosh GH, Le Leu RK, et al. (2008) Suppression of colorectal oncogenesis by selenium-enriched milk proteins: apoptosis and K-ras mutations. Cancer Res 68, 4936-4944.

10. Gromadzinska J, Reszka E, Bruzelius K, et al. (2008) Selenium and cancer: biomarkers of selenium status and molecular action of selenium supplements. Eur J Nutr 47, Suppl. 2, 29-50.

11. Pagmantidis V, Meplan C, van Schothorst EM, et al. (2008) Supplementation of healthy volunteers with nutritionally relevant amounts of selenium increases the expression of lymphocyte protein biosynthesis genes. Am J Clin Nutr 87, 181-189.

12. Mork H, Lex B, Scheurlen M, et al. (1998) Expression pattern of gastrointestinal selenoproteins - targets for selenium supplementation. Nutr Cancer 32, 64-70.

13. Early DS, Hill K, Burk R, et al. (2002) Selenoprotein levels in patients with colorectal adenomas and cancer. Am J Gastroenterol 97, 745-748.

14. Peters U, Chatterjee N, Hayes RB, et al. (2008) Variation in the selenoenzyme genes and risk of advanced distal colorectal adenoma. Cancer Epidemiol Biomarkers Prev 17, 1144-1154.

15. Chu FF, Esworthy RS, Chu PG, et al. (2004) Bacteria-induced intestinal cancer in mice with disrupted Gpxl and Gpx2 genes. Cancer Res 64, 962-968.

16. Irons R, Carlson BA, Hatfield DL, et al. (2006) Both selenoproteins and low molecular weight selenocompounds reduce colon cancer risk in mice with genetically impaired selenoprotein expression. J Nutr 136, 1311-1317.

17. Meplan C, Crosley LK, Nicol F, et al. (2007) Genetic polymorphisms in the human selenoprotein $\mathrm{P}$ gene determine the response of selenoprotein markers to selenium supplementation in a gender-specific manner (the SELGEN study). FASEB J 21, 3063-3074.

18. Pagmantidis V, Bermano G, Villette S, et al. (2005) Effects of Se-depletion on glutathione peroxidase and selenoprotein W gene expression in the colon. FEBS Lett 579, 792-796.

19. Rayman MP (2009) Selenoproteins and human health: insights from epidemiological data. Biochim Biophys Acta 1790, $1533-1540$.

20. Elsom R, Sanderson P, Hesketh JE, et al. (2006) Functional markers of selenium status: UK Food Standards Agency workshop report. Br J Nutr 96, 980-984.

21. Brigelius-Flohe R, Muller C, Menard J, et al. (2001) Functions of GI-GPx: lessons from selenium-dependent expression and intracellular localization. Biofactors 14, 101-106.

22. Kipp A, Banning A, van Schothorst EM, et al. (2009) Four selenoproteins, protein biosynthesis, and Wnt signalling are particularly sensitive to limited selenium intake in mouse colon. Mol Nutr Food Res 53, 1561-1572.

23. Anonymous (1977) Report of the American Institute of Nurtition ad hoc Committee on Standards for Nutritional Studies. J Nutr 107, 1340-1348. 
24. Simon P (2003) Q-Gene: processing quantitative real-time RT-PCR data. Bioinformatics 19, 1439-1440.

25. Hill KE, Zhou J, McMahan WJ, et al. (2003) Deletion of selenoprotein $\mathrm{P}$ alters distribution of selenium in the mouse. $J$ Biol Chem 278, 13640-13646.

26. Hoffmann PR, Hoge SC, Li PA, et al. (2007) The selenoproteome exhibits widely varying, tissue-specific dependence on selenoprotein P for selenium supply. Nucleic Acids Res 35, 3963-3973.

27. Weiss SL, Evenson JK, Thompson KM, et al. (1996) The selenium requirement for glutathione peroxidase mRNA level is half of the selenium requirement for glutathione peroxidase activity in female rats. $J$ Nutr 126, 2260-2267.

28. Weiss Sachdev S \& Sunde RA (2001) Selenium regulation of transcript abundance and translational efficiency of glutathione peroxidase-1 and -4 in rat liver. Biochem J 357, 851-858.

29. Wingler K, Muller C, Schmehl K, et al. (2000) Gastrointestinal glutathione peroxidase prevents transport of lipid hydroperoxides in CaCo-2 cells. Gastroenterology 119, 420-430.

30. Behne D \& Wolters W (1983) Distribution of selenium and glutathione peroxidase in the rat. J Nutr 113, 456-461.

31. Facompre N \& El-Bayoumy K (2009) Potential stages for prostate cancer prevention with selenium: implications for cancer survivors. Cancer Res 69, 2699-2703.

32. Neve J (1995) Human selenium supplementation as assessed by changes in blood selenium concentration and glutathione peroxidase activity. J Trace Elem Med Biol 9, 65-73.

33. Ip C (1998) Lessons from basic research in selenium and cancer prevention. J Nutr 128, 1845-1854.

34. Whanger PD \& Butler JA (1988) Effects of various dietary levels of selenium as selenite or selenomethionine on tissue selenium levels and glutathione peroxidase activity in rats. J Nutr 118, 846-852.

35. Rayman MP (2004) The use of high-selenium yeast to raise selenium status: how does it measure up? Br J Nutr 92, 557-573.

36. Sunde RA, Paterson E, Evenson JK, et al. (2008) Longitudinal selenium status in healthy British adults: assessment using biochemical and molecular biomarkers. Br J Nutr 99, Suppl. 3, S37-S47.

37. Esworthy RS, Swiderek KM, Ho YS, et al. (1998) Seleniumdependent glutathione peroxidase-GI is a major glutathione peroxidase activity in the mucosal epithelium of rodent intestine. Biochim Biophys Acta 1381, 213-226.

38. Diwadkar-Navsariwala V, Prins GS, Swanson SM, et al. (2006) Selenoprotein deficiency accelerates prostate carcinogenesis in a transgenic model. Proc Natl Acad Sci U S A 103, 8179-8184.

39. Al-Taie OH, Uceyler N, Eubner U, et al. (2004) Expression profiling and genetic alterations of the selenoproteins GI-GPx and SePP in colorectal carcinogenesis. Nutr Cancer 48, 6-14.

40. Persson-Moschos ME, Stavenow L, Akesson B, et al. (2000) Selenoprotein $\mathrm{P}$ in plasma in relation to cancer morbidity in middle-aged Swedish men. Nutr Cancer 36, 19-26.

41. Chu FF, Esworthy RS \& Doroshow JH (2004) Role of Se-dependent glutathione peroxidases in gastrointestinal inflammation and cancer. Free Radic Biol Med 36, 1481-1495.
42. Hu Y, Benya RV, Carroll RE, et al. (2005) Allelic loss of the gene for the GPX1 selenium-containing protein is a common event in cancer. $J$ Nutr 135, 3021S-3024S

43. Chu FF, Esworthy RS, Ho YS, et al. (1997) Expression and chromosomal mapping of mouse Gpx2 gene encoding the gastrointestinal form of glutathione peroxidase, GPX-GI Biomed Environ Sci 10, 156-162.

44. Bartel J, Bartz T, Wolf C, et al. (2007) Activity of the glutathione peroxidase-2. Differences in the selenium-dependent expression between colon and small intestine. Cancer Genomics Proteomics 4, 369-372.

45. Banning A, Kipp A, Schmitmeier S, et al. (2008) Glutathione peroxidase 2 inhibits cyclooxygenase-2-mediated migration and invasion of HT-29 adenocarcinoma cells but supports their growth as tumors in nude mice. Cancer Res $\mathbf{6 8}$, 9746-9753.

46. Kipp A, Banning A \& Brigelius-Flohe R (2007) Activation of the glutathione peroxidase 2 (GPx2) promoter by $\beta$-catenin. Biol Chem 388, 1027-1033.

47. Banning A, Deubel S, Kluth D, et al. (2005) The GI-GPx gene is a target for Nrf2. Mol Cell Biol 25, 4914-4923.

48. Mork $\mathrm{H}$, al-Taie $\mathrm{OH}, \mathrm{Bahr} \mathrm{K}$, et al. (2000) Inverse mRNA expression of the selenocysteine-containing proteins GI-GPx and $\mathrm{SeP}$ in colorectal adenomas compared with adjacent normal mucosa. Nutr Cancer 37, 108-116.

49. Murawaki Y, Tsuchiya H, Kanbe T, et al. (2008) Aberrant expression of selenoproteins in the progression of colorectal cancer. Cancer Lett 259, 218-230.

50. Fiala ES, Joseph C, Sohn OS, et al. (1991) Mechanism of benzylselenocyanate inhibition of azoxymethane-induced colon carcinogenesis in F344 rats. Cancer Res 51, 2826-2830.

51. Jacobs ET, Jiang R, Alberts DS, et al. (2004) Selenium and colorectal adenoma: results of a pooled analysis. $J$ Natl Cancer Inst 96, 1669-1675.

52. Rao CV, Wang CQ, Simi B, et al. (2001) Chemoprevention of colon cancer by a glutathione conjugate of 1,4-phenylenebis (methylene)selenocyanate, a novel organoselenium compound with low toxicity. Cancer Res 61, 3647-3652.

53. Thomson CD (2004) Assessment of requirements for selenium and adequacy of selenium status: a review. Eur J Clin Nutr 58, 391-402.

54. Moghadaszadeh B \& Beggs AH (2006) Selenoproteins and their impact on human health through diverse physiological pathways. Physiology (Bethesda) 21, 307-315.

55. Diwadkar-Navsariwala V \& Diamond AM (2004) The link between selenium and chemoprevention: a case for selenoproteins. J Nutr 134, 2899-2902.

56. Bermano G, Nicol F, Dyer JA, et al. (1995) Tissue-specific regulation of selenoenzyme gene expression during selenium deficiency in rats. Biochem $J$ 311, 425-430.

57. Ganther HE (1999) Selenium metabolism, selenoproteins and mechanisms of cancer prevention: complexities with thioredoxin reductase. Carcinogenesis 20, 1657-1666. 